\title{
PENGARUH JARAK ANTAR PIPA PADA KOLEKTOR TERHADAP PANAS YANG DIHASILKAN SOLAR WATER HEATER (SWH)
}

\author{
Helmi Susanto ${ }^{*}$, Dwi Irawan² \\ Jurusan Teknik Mesin, Fakultas Teknik, Universitas Muhammadiyah Metro \\ Jl. Ki Hajar Dewantara 15 A Metro, Lampung \\ Email: helmisusanto77@yahoo.co.id ${ }^{1}$,dwi_irawan@yahoo.co.id²
}

\begin{abstract}
Abstrak
Energi surya yang sampai kepermukaan bumi dapat dikonversi menjadi energi panas dengan menggunakan kolektor surya. Didalam kolektor terdapat beberapa komponen diantaranya pipa pemanas sebagai media untuk mengalirkan air kedalam tangki penyimpanan. Ada beberapa faktor yang mempengaruhi kinerja kolektor surya diantaranya yaitu jarak ataupun diameter belokan. Penelitian ini bertujuan untuk mengetahui perpindahan panas yang terjadi pada kolektor pemanas air tenaga surya dengan variasi jarak antar pipa tembaga serta mengetahui efisiensi perubahan panas yang terjadi dan mengetahui berapakah ukuran pipa pemanas yang tepat pada pemanas air tenaga surya. Metode penelitiannya dilakukan dengan beberapa tahap yaitu studi pustaka, pembuatan alat, pengujian dan analisis hasil penelitian. Variasi jarak pipa tembaga yaitu $5 \mathrm{~cm}, 7 \mathrm{~cm}$ dan $9 \mathrm{~cm}$. Dari hasil penelitian diperoleh bahwa perpindahan panas konveksi yang paling besar dengan jarak pipa tembaga $5 \mathrm{~cm}$ yaitu 549,73 watt pada intensitas matahari tertinggi $723,33 \mathrm{~W} / \mathrm{m}^{2}$ dengan efisiensi perubahan suhu sebesar $33,33 \%$. Sedangkan dengan jarak pipa $7 \mathrm{~cm}$ perpindahan panas konveksi yang terjadi sebesar 256,33 watt pada intensitas tertinggi mencapai $758,67 \mathrm{~W} / \mathrm{m}^{2}$ dengan efisiensi perubahan suhu sebesar 21,98\%. Dan jarak pipa $9 \mathrm{~cm}$ perpindahan panas konveksi yang terjadi sebesar 101,74 watt pada intensitas matahari tertinggi $813,33 \mathrm{~W} / \mathrm{m}^{2}$ dengan efisiensi perubahan suhu sebesar $13,33 \%$.
\end{abstract}

Kata Kunci: Jarak Pipa, Kolektor Surya, Solar Water Heater.

\section{Pendahuluan}

Energi surya merupakan salah sumber energi terbarukan. Energi surya yang sampai kepermukaan bumi dapat dikonversi menjadi energi panas dengan menggunakan alat yang disebut kolektor surya. Kolektor surya merupakan suatu peralatan yang digunakan untuk menyerap energi surya yang kemudian mengubah energi surya menjadi energi termal, dan mentransfer energi tersebut ke fluida kerja untuk kemudian digunakan secara langsung atau disimpan terlebih dahulu pada suatu unit penyimpanan panas. Dalam aplikasinya kolektor termal surya banyak digunakan sebagai alat pemanas air pada rumah-rumah dan salah satu titik penggunaan energi yang cukup besar adalah di Indonesia [1].
Kolektor pemanas air mempunyai komponen-komponen diantaranya adalah kaca penutup sebagai media penerima sinar radiasi langsung dari matahari, absorber sebagai media yang menyerap panas yang telah diterima oleh kaca penutup, isolator sebagai media yang berguna untuk menahan terbuangnya sisa-sisa panas yang telah terkumpul di dalam kolektor pemanas, dan yang terakhir yaitu pipa pemanas sebagai media yang berguna untuk tempat dimana air akan dipanaskan oleh sinar radiasi matahari langsung, pipa ini akan dialiri air dingin yang belum terkena radiasi sinar matahari dari tangki dan setelah air yang ada dalam pipa ini sudah dalam kondisi panas maka pipa-pipa ini juga yang menjadi media untuk mengalirkan air ke dalam tangki penyimpanan. 
Pipa Kolektor surya yang berfungsi sebagai pengalir dan penyalur air ini umumnya menggunakan bahan tembaga karena tahan terhadap sifat korosif dan salah satu bahan yang memiliki konduktivitas termal yang baik yaitu sebesar 393,56 $\mathrm{W} / \mathrm{m} . \mathrm{K}[2]$.

Pipa-pipa tembaga pada kolektor surya dibentuk menjadi serpentine dengan cara membengkokkan pipa tembaga. Model serpentine ini dipilih dikarenakan dapat meminimalisir tempat atau luasan dari kolektor namun tidak mengurangi jumlah ataupun panjang dari pipa sehingga tetap dapat menghasilkan kinerja yang baik. Bentuk serpentine juga akan mempengaruhi kecepatan fluida menjadi lebih lambat sebelum masuk kedalam tandon air ataupun tangki penyimpanan sehingga dapat meningkatkan suhu air [3].

Ada beberapa faktor yang mempengaruhi kinerja kolektor pemanas surya yaitu jarak dan diameter belokan pipa. Semakin rapat jarak antar pipa maka akan mendapatkan efisiensi kolektor yang semakin besar [4]. Dan semakin banyak jumlah pipa-pipa pemanas maka akan mendapatkan energi berguna yang dihasilkan oleh kolektor semakin besar, dimana pengaruh jumlah pipa pemanas terhadap perubahan energi berguna sangatlah penting dikarenakan proses perpindahan panas dari absorber ke air yang mengalir didalam pipa pemanas lebih efektif pada jumlah pipa yang lebih banyak [2].

Dalam penelitian ini akan menganalisa dan mengkaji bagaimana pengaruh dari jarak antar pipa terhadap panas yang dihasilkan kolektor pemanas air tenaga surya dan berapa besar efisiensi perubahan suhu yang terjadi pada jarak antar pipa yang dihasilkan kolektor pemanas air tenaga surya untuk dapat menentukan jarak antar pipa yang tepat dan baik pada pemanas air tenaga surya.

\section{Tinjauan Pustaka}

Penelitian yang dilakukan oleh Kristanto dan San dapat disimpulkan bahwa semakin tebal plat penyerap dan semakin rapat jarak antar pipa, maka semakin besar efisiensi sirip kolektor. Hal ini terjadi pada jarak anatar pipa 73,6 mm dengan ketebalan plat penyerap 1,2 $\mathrm{mm}$ dengan efisiensi sirip 99,53\% [4].

Penelitian yang dilakukan oleh Sudrajat dan Santosa dapat disimpulkan bahwa panjang pipa pemanas keseluruhan yang dibutuhkan untuk membuat solar water heater dengan temperatur air keluar $\left(\mathrm{T}_{\text {out }}\right)$ $45^{\circ} \mathrm{C}$ adalah 1,63 $\mathrm{m}$ dan terbuat dari bahan jenis tembaga berdiameter 0,5 inch [5].

Penelitian yang dilakukan oleh Sumarsono dapat disimpulkan bahwa untuk keperluan produksi air panas PATS (Pemanas Air Tenaga Surya), besarnya energi berguna sangat menentukan. Energi berguna optimum dapat dihasilkan oleh kolektor dengan jumlah pipa pemanas sebanyak 6 pipa dan 8 pipa [2].

Penelitian yang dilakukan oleh Mustofa dan Rustan dapat disimpulkan bahwa efisiensi kolektor meningkat dengan adanya modifikasi jenis material, serial konfigurasi dan dimensi pipa panas. Hal ini disebabkan oleh konduktivitas panas material yang berbeda, sehingga daya isolasi air panas dalam tandon stainlees steel lebih baik dibandingkan dengan dari bahan fiberglass, selanjutnya peningkatan suhu air sirkulasi dari paralel ke serpentine menjadi lebih tinggi karena kecepatan fluida menjadi lambat pada model serpentine sebelum masuk kedalam tendon [3].

Pemanas air tenaga surya adalah suatu alat yang berguna untuk mengumpulkan energi panas yang dipancarkan oleh matahari dimana alat ini berfungsi untuk menyerap panas dari matahari untuk selanjutnya akan digunakan untuk memanaskan air yang ada di dalam pipa tembaga yang ada pada kolektor surya. Prinsip kerja dari pemanas air tenaga surya yaitu dengan memanfaatkan energi radiasi matahari yang diserap oleh absorber, kemudian air panas ditampung didalam tangki yang diisolasi. Fluida mengalir dengan cara memanfaatkan perbedaan massa jenis air di dalam tangki. Beberapa sistem pemanas telah dilengkapi dengan 
heater tambahan sehingga dapat memanaskan air walaupun tidak ada sinar matahari. Pemanas air tenaga surya yang paling umum adalah jenis pemanas air tenaga surya plat datar (flat plate solar water heater). Kekurangannya adalah pemasangan yang lebih rumit (diletakkan di atas atap rumah) dan panas yang dihasilkan tidak cukup untuk memanaskan air yang ada, maka pemanas listrik yang ada bekerja untuk memanaskan air. Jadi dibutuhkan energi listrik tambahan lagi [6].

Kolektor pemanas air tenaga surya memiliki beberapa bagian atau komponen yang melengkapinya yaitu diantaranya yaitu Penutup transparan, Pipa kolektor, Sirip kolektor, Rumah kolektor, Isolator [7].

Penutup transparan yang bersifat meneruskan/mentransmisikan sinar radiasi yang diterima, mengurangi kerugian panas konveksi serta melindungi pipa-pipa kolektor. Untuk itu diperlukan material dengan transmivitas tinggi, absorbsivitas dan refleksi yang rendah serta tahan terhadap temperature tinggi. Material kaca dipergunakan sebagai penutup transparan karena memiliki koefisien transmisi yang cukup tinggi.

Pipa kolektor berfungsi sebagai media pemindah panas dari radiasi panas yang diterima ke media air sebagai penyerap energi panas. Penggunaan material tembaga sebagai pipa kolektor cukup bagus mengingat tembaga memiliki koefisien konduktivitas panas sebesar $401 \mathrm{~W} / \mathrm{m} . \mathrm{K}$.

Sirip kolektor yang membantu menyerap radiasi sinar matahari dan menghantarkannya ke pipa kolektor, sehingga diperlukan material yang memiliki konduktivitas dan absorbsivitas tinggi serta tahan terhadap temperature tinggi;

Rumah kolektor yang berfungsi sebagai dudukan semua komponen solar kolektor; dan isolator merupakan bahan yang digunakan untuk mengurangi kebocoran kalor pada rumah kolektor.

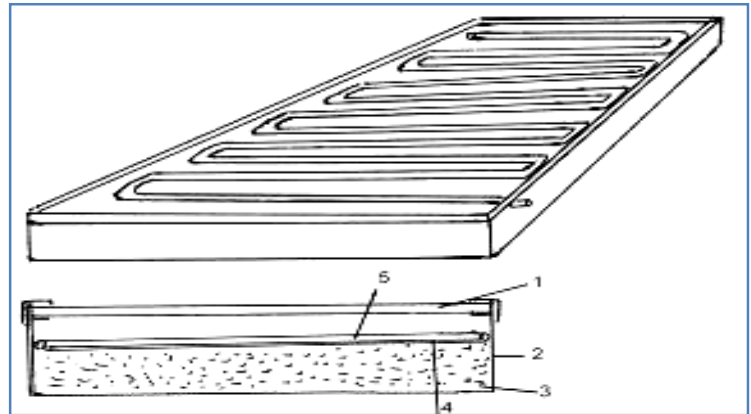

Gambar 1. Komponen kolektor surya

Keterangan :
1. Kaca penutup
2. Kotak kolektor
3. Isolator,
4. Plat penyerap
5. Pipa air

Tinjauan prestasi dari kolektor surya dengan variasi jarak antar pipa terhadap panas yang dihasilkan pemanas air tenaga surya ditunjukkan dengan beberapa parameter-parameter penting yang akan dikaji menurut proses kinerja dari alat tersebut. Adapun beberapa parameter tersebut ialah energi berguna pada kolektor pemanas air tenaga surya dan laju perpindahan panas yang terjadi terhadap jarak antar pipa.

Perpindahan panas terjadi karena adanya perbedaan suhu. Panas akan mengalir dari tempat yang suhunya tinggi ke tempat yang suhunya lebih rendah. Perpindahan panas terjadi menurut tiga mekanisme yaitu konduksi, konveksi dan radiasi.

Perpindahan panas konduksi adalah proses perpindahan panas jika panas mengalir dari tempat yang suhunya tinggi ke tempat yang suhunya lebih rendah, tetapi media untuk perpindahan panas tetap.

Persamaan dasar dari konsep perpindahan panas konduksi adalah hukum fourier. Hukum fourier dinyatakan dengan persamaan berikut [8].

$$
q_{k}=-k A \frac{d T}{d X}
$$

atau

$$
\frac{q_{k}}{A}=k\left[-\frac{d T}{d X}\right]
$$


Dimana :

$\mathrm{T}=\mathrm{Suhu},{ }^{0} \mathrm{C}\left({ }^{0} \mathrm{~F}\right)$

$\mathrm{X}=$ Jarak/tebal dinding, $\mathrm{m}(\mathrm{ft})$

$\mathrm{A}=$ Luas dinding (luas perpindahan panas), $\mathrm{m}^{2}\left(\mathrm{ft}^{2}\right)$

$\mathrm{K}=$ Konduktivitas termal, $\mathrm{W} / \mathrm{m} \cdot{ }^{0} \mathrm{C}$ (Btu/h.ft. $\left.{ }^{0} \mathrm{~F}\right)$ proporsional)

(Konstanta

$\mathrm{q}_{\mathrm{k}}=$ Laju perpindahan panas konduksi, Watt (Btu/h)

$\frac{q_{k}}{A}=$ Laju perpindahan panas per satuan luas (heat flux) W/m² (Btu/h. $f t^{2}$ )

Untuk mengetaui perpindahan panas konduksi pada silinder (pipa) dapat digunakan persamaan sebagai berikut [9].

$$
q_{k}=-K A \frac{d T}{d R}
$$

Untuk silinder berlubang, luasnya merupakan fungsi jari-jari dan $r$ adalah jarijari dan L panjang silinder [9].

$$
A=2 \pi \times r \times L
$$

Dimana:

$\mathrm{dT}=$ Perubahan suhu dari fluida dingin ke fluida panas $\left({ }^{\circ} \mathrm{C}\right)$

$\mathrm{dR}=$ Perbandingan jari-jari silinder atau pipa bagian luar dan bagian dalam (m)

$\mathrm{A}=$ Luas penampang permukaan silinder atau pipa $\left(\mathrm{m}^{2}\right)$

$\mathrm{r} \quad=$ Jari-jari silinder atau pipa (m)

$\mathrm{L}=$ Panjang silinder atau panjang pipa (m)

Perpindahan panas konveksi adalah proses perpindahan dimana cairan atau gas yang suhunya tinggi mengalir ke tempat yang suhunya lebih rendah, memberikan panas pada permukaan yang suhunya lebih rendah.

Perpindahan panas terjadi antara permukaan padat dengan fluida yang mengalir di sekitarnya. Jadi perpindahan panas ini memerlukan media penghantar berupa fluida (cairan atau gas).

Perpindahan panas secara konveksi terjadi melalui 2 cara yaitu konveksi alami dan konveksi paksa. Konveksi bebas/konveksi alamiah (free convection/natural convection) Adalah perpindahan panas yang disebabkan oleh beda suhu dan beda rapat saja tenaga dari luar yang mendorongnya. Contoh: plat panas yang dibiarkan berada di udara sekitar tanpa ada sumber gerakan dari luar. Konveksi paksaan (forced convection) Adalah perpindahan panas yang aliran gas atau cairannya di sebabkan adanya tenaga dari luar. Contoh: plat panas dihembus udara dengan kipas/blower.

Persamaan dasar dari konsep perpindahan panas konveksi adalah hukum Newton. Hukum Newton dinyatakan denganpersamaan berikut [8]:

$$
q_{c}=h_{c} \times A \times \Delta T
$$

Dimana $h_{c}$ dipeoleh dengan persamaan berikut [10].

$$
h_{c}=N_{U} \frac{k_{f}}{D}
$$

Dimana :

$\Delta T=$ Perbedaan suhu ${ }^{0} \mathrm{C}\left({ }^{0} \mathrm{~F}\right)$

$\mathrm{A}=$ Luas dinding (luas perpindahan panas), $\mathrm{m}^{2}\left(\mathrm{ft}^{2}\right)$

$\mathrm{h}_{\mathrm{c}}=\quad$ Koefisien perpindahan konveksi (convection heat transfer coefficient $), \mathrm{W} / \mathrm{m}^{2} .{ }^{0} \mathrm{C}\left(\mathrm{Btu} / \mathrm{h} . \mathrm{ft} .{ }^{0} \mathrm{~F}\right)$ (konstanta proporsionalitas)

$\mathrm{q}_{\mathrm{c}}$ = Laju perpindahan panas konveksi, Watt (Btu/h)

$\mathrm{k}_{\mathrm{f}}=$ Konduktivitas termal fluida $\left(0,556 \mathrm{~W} / \mathrm{M}^{\circ} \mathrm{C}\right.$, diambil dari tabel pada lampiran 15)

$\mathrm{N}_{\mathrm{U}}=$ Angka nusselt $\left(4,36, \mathrm{R}_{\mathrm{e}} \leq 2300\right)$

Perpindahan panas radiasi adalah perpindahan panas yang terjadi karena pancaran/ sinaran/radiasi gelombang elektromagnetik.

Perpindahan panas radiasi berlangsung elektromagnetik dengan panjang gelombang pada interval tertentu. Jadi perpindahan panas radiasi tidak memerlukan media, sehingga perpindahan panas dapat berlangsung dalam ruangan hampa udara. Contoh : panas matahari yang sampai ke bumi.

Benda yang dapat memancarkan panas dengan sempurna disebut radiator yang sempurna dan dikenal sebagai benda hitam (black body). Sedangkan benda yang tidak dapat memancarkan panas dengan sempurna disebut dengan benda abu-abu (gray body). 
Persamaan dasar dari konsep perpindahan panas radiasi adalah hukum Stefan Boltzman. Hukum Stefan Boltzman dinyatakan dengan persamaan berikut [8].

$$
q_{r}=\varepsilon \sigma A T^{4}
$$

Dimana :

$$
\begin{aligned}
\varepsilon & =\text { Emisivitas } \\
\mathrm{T} & =\text { Suhu absolute benda, } \mathrm{K}\left({ }^{0} \mathrm{R}\right) \\
\mathrm{A} & =\text { Luas permukaan, } \mathrm{m}^{2}\left(\mathrm{ft}^{2}\right) \\
\mathrm{q} \mathrm{r} & =\text { Laju perpindahan panas radiasi, } \\
& \text { Watt }(\mathrm{Btu} / \mathrm{h}) \\
\sigma & =\text { Konstanta Stefan-Boltzman, } 5,669 \\
& \times 10^{-8} \mathrm{~W} / \mathrm{m}^{2} \cdot \mathrm{K}^{4} \quad\left(0,1713 \times 10^{-8}\right. \\
& \text { Btu/h. } \left.\cdot \mathrm{ft}^{2} \cdot{ }^{0} \mathrm{R}^{4}\right) \\
& (\text { konstanta proporsionalitas })
\end{aligned}
$$

Untuk benda hitam, emisivitasnya berharga satu, sedangkan untuk benda abuabu, nilai emisivitasnya selalu lebih dari satu.

Adapun efisiensi perpindahan panas yang terjadi pada pipa tembaga didalam kolektor pemanas air tenaga surya untuk memanaskan air sebanyak 50 liter dapat digunakan persamaan sebagai berikut:

$$
\eta=\frac{T_{o u t}-T_{\text {in }}}{T_{\text {in }}} \times 100 \%
$$

Dimana:

$\eta=$ Efisiensi perpindahan panas yang terjadi pada pipa tembaga didalam kolektor pemanas air tenaga surya $(\%)$

$T_{\text {in }}=$ Suhu air masuk kedalam pipa tembaga $\left({ }^{\circ} \mathrm{C}\right)$

$T_{\text {out }}=$ Suhu air keluar pipa tembaga $\left({ }^{\circ} \mathrm{C}\right)$

\section{Metode Penelitian}

Lokasi penelitian dilakukan di kampus 2 Universitas Muhammadiyah Metro. Penelitian ini dilakukan dengan metode eksperimen nyata (true experimental research). Metode eksperimen meliputi tahap perencanaan, pembuatan, sampai dengan mengujian kolektor surya.

\section{Langkah penelitian meliputi:}

1. Studi pustaka

2. Pembuatan kolektor surya

3. Pengujian kolektor surya

4. Analisis hasil eksperimen
Spesifikasi alat uji dalam penelitian pengaruh jarak pipa pada kolektor terhadap panas yang dihasilkan solar water heater adalah sebagai berikut:

a. Kolektor terbuat dari bahan alumunium dengan panjang kolektor $90 \mathrm{~cm}$, lebar kolektor $40 \mathrm{~cm}$ dan tinggi kolektor 10 $\mathrm{cm}$;

b. Kaca penutup kolektor berbahan kaca bening dengan ketebalan $3 \mathrm{~mm}$ sebanyak 1 buah;

c. Absorber yang digunakan berbahan stanlees steel yang dicat hitam dengan panjang $80 \mathrm{~cm}$ dan lebar $35 \mathrm{~cm}$;

d. Pipa cairan yang digunakan berbahan tembaga dengan ukuran $1 / 2$ inchi dengan tebal 0,61 mm;

e. Pada jarak pipa $5 \mathrm{~cm}$ terdapat 13 buah pipa dengan belokan sebanyak 14 buah belokan, dengan panjang pipa $455 \mathrm{~cm}$ dan lebar pipa $30 \mathrm{~cm}$;

f. Pada jarak pipa $7 \mathrm{~cm}$ terdapat 9 buah pipa dengan belokan sebanyak 10 buah belokan, dengan panjang pipa $333 \mathrm{~cm}$ dan lebar pipa $30 \mathrm{~cm}$;

g. Pada jarak pipa $9 \mathrm{~cm}$ terdapat 7 buah pipa dengan belokan sebanyak 8 buah belokan, dengan panjang pipa $273 \mathrm{~cm}$ dan lebar $30 \mathrm{~cm}$; dan

h. Isolator menggunakan bahan glass wool dengan ketebalan $5 \mathrm{~cm}$.

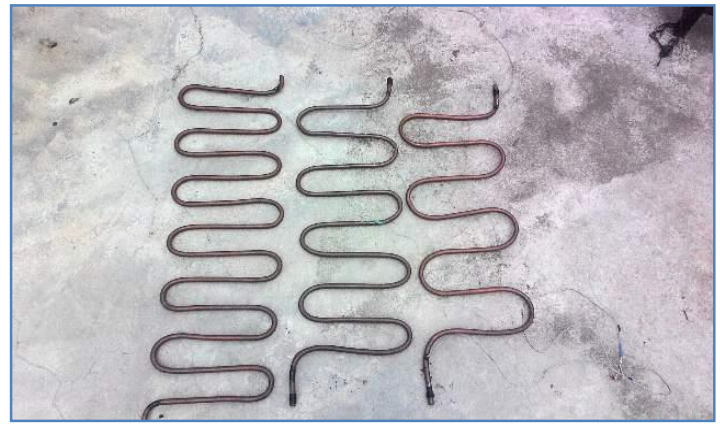

Gambar 2. Pipa tembaga model serpentine dengan ukuran jarak antar pipa $5 \mathrm{~cm}, 7 \mathrm{~cm}$ dan $9 \mathrm{~cm}$

\section{Hasil}

Pada kolektor surya terjadi perpindahan panas konveksi bebas (alami) yang terjadi pada saat proses pemanasan didalam pipa tembaga. Aliran fluida terjadi karena perbedaan massa jenis fluida antara air 
panas dan air dingin. Aliran fluida di dalam pipa tembaga ini cenderung lambat atau laminer.

Dari pengolahan data yang diperoleh maka didapat hasil yaitu:

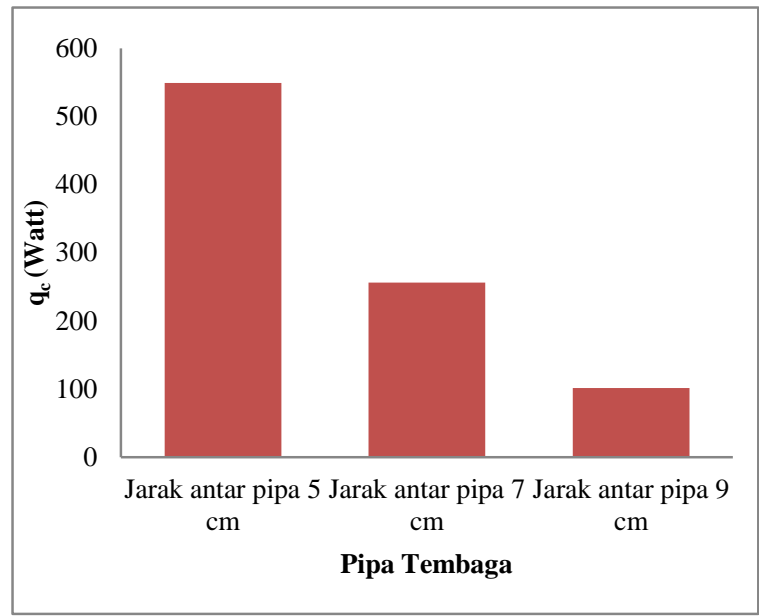

Gambar 3. Grafik Laju Perpindahan Panas Konveksi Pada Fluida Pada Intensitas Matahari Tertinggi

Untuk pipa tembaga jarak $5 \mathrm{~cm}$, perpindahan panas konveksi yang terjadi sebesar 549,73 watt dengan intensitas matahari tertinggi $723,33 \mathrm{~W} / \mathrm{m}^{2}$ pada pukul 12.30 .

Sedangkan untuk pipa tembaga jarak $7 \mathrm{~cm}$, perpindahan panas konveksi yang terjadi adalah sebesar 256,33 watt dengan intensitas matahari tertinggi $758,67 \mathrm{~W} / \mathrm{m}^{2}$ pada pukul 11.00. Dan untuk pipa tembaga jarak $9 \mathrm{~cm}$, perpindahan panas konveksi yang terjadi sebesar 101,74 watt dengan intensitas matahari tertinggi $813,33 \mathrm{~W} / \mathrm{m}^{2}$ pada pukul 12.30 .

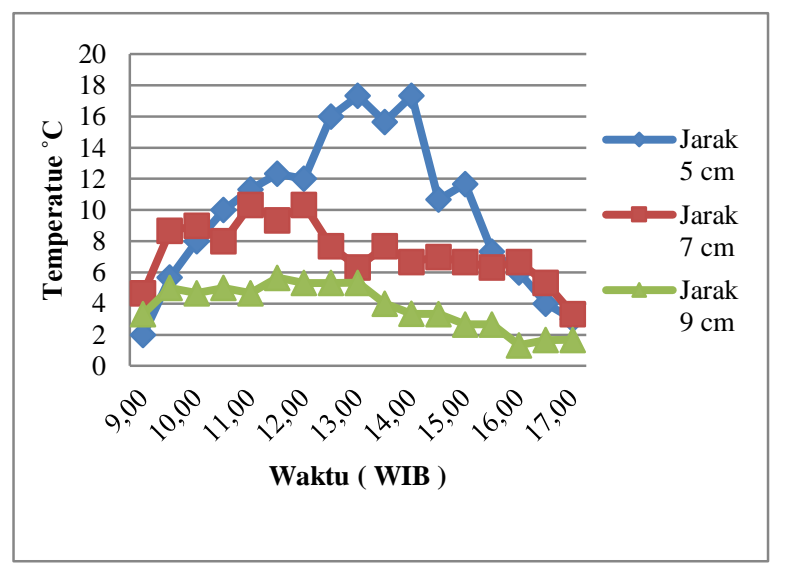

Gambar 4. Grafik Perubahan Suhu RataRata Air Didalam Pipa Tembaga Jarak 5 $\mathrm{Cm}, 7 \mathrm{Cm}$ Dan $9 \mathrm{Cm}$

Dapat dilihat dari grafik perubahan suhu rata-rata air di dalam pipa tembaga untuk pipa tembaga jarak $5 \mathrm{~cm}$ perubahan suhu yang terjadi lebih tinggi dibandingkan perubahan suhu yang terjadi pada jarak $7 \mathrm{~cm}$ dan $9 \mathrm{~cm}$.

Dimana perbuahan suhu yang terjadi pada pipa jarak $5 \mathrm{~cm}$ maksimal mencapai $17,33^{\circ} \mathrm{C}$, sedangkan perubahan suhu maksimal yang terjadi pada jarak $7 \mathrm{~cm}$ mencapai $10,33^{\circ} \mathrm{C}$ dan untuk jarak $9 \mathrm{~cm}$ perubahan suhu maksimalnya mecapainya $5.66^{\circ} \mathrm{C}$.

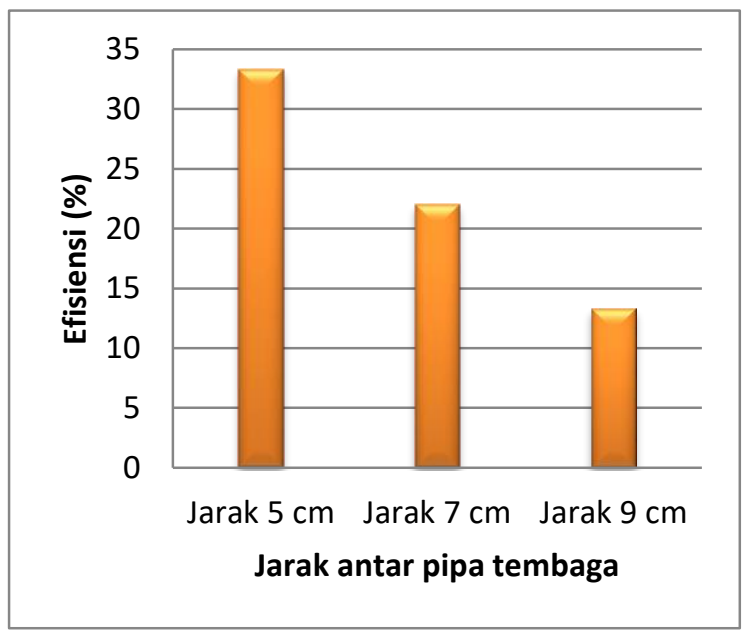

Gambar 5. Grafik Efisiensi Perubahan Suhu Rata-Rata Pada Intensitas Matahari Tertinggi

Dilihat dari grafik efisiensi perubahan suhu rata-rata pada intensitas matahari tertinggi, pipa tembaga jarak $5 \mathrm{~cm}$ lebih tinggi dibandingkan jarak $7 \mathrm{~cm}$ dan 9 $\mathrm{cm}$, dimana efisiensi perubahan suhu $5 \mathrm{~cm}$ sebesar $33.33 \%$, sedangkan untuk jarak $7 \mathrm{~cm}$ sebesar 21,98\% dan jarak $9 \mathrm{~cm}$ sebesar 13,33\%.b dari grafik efisiensi perubahan suhu dapat diketahui bahwa jarak antar pipa $5 \mathrm{~cm}$ lebih baik diantara jarak antar pipa 7 $\mathrm{cm}$ dan $9 \mathrm{~cm}$, karena adanya perbedaan luas penampang pipa pada jarak antar pipa $5 \mathrm{~cm}$, $7 \mathrm{~cm}$ dan $9 \mathrm{~cm}$, dimana membuat jumlah pipa pada jarak antar pipa $5 \mathrm{~cm}$ menjadi lebih banyak dan membuat selisih perubahan suhu tertinggi terjadi pada jarak 
antar pipa $5 \mathrm{~cm}$ menjadi lebih besar yaitu sebesar $17,33{ }^{\circ} \mathrm{C}$. Sehingga pada jarak antar pipa $5 \mathrm{~cm}$ mendapatkan efisiensi perubahan suhu tertinggi sebesar 33, 33\% dari pada pipa jarak antar pipa $7 \mathrm{~cm}$ dan $9 \mathrm{~cm}$.

\section{Kesimpulan}

Dari penelitian yang telah dilakukan maka dapat disimpulkan bahwa:

1. Laju perpindahan panas yang terjadi pada pipa tembaga jarak antar pipa $5 \mathrm{~cm}$ adalah perpindahan panas secara konveksi sebesar 549,73 watt dengan intensitas matahari tertinggi 723,33 $\mathrm{W} / \mathrm{m}^{2}$, sedangkan untuk pipa tembaga jarak antar pipa $7 \mathrm{~cm}$ perpindahan panas konveksi yang terjadi sebesar 256,33 watt dengan intensitas matahari tertinggi mencapai $758,67 \mathrm{~W} / \mathrm{m}^{2}$ dan untuk pipa tembaga jarak antar pipa 9 $\mathrm{cm}$ perpindahan panas konveksi yang terjadi adalah sebesar 101,74 watt dengan intensitas matahari tertinggi $813,33 \mathrm{~W} / \mathrm{m}^{2}$.

2. Efisiensi perubahan suhu rata-rata pada intensitas matahari tertinggi untuk pipa tembaga jarak antar pipa $5 \mathrm{~cm}$ sebesar $33.33 \%$, sedangkan untuk pipa tembaga jarak antar pipa $7 \mathrm{~cm}$ sebesar 21,98\% dan untuk pipa tembaga jarak antar pipa $9 \mathrm{~cm}$ sebesar $13,33 \%$.

3. Jarak antar pipa tembaga dengan model serpentine yang ideal adalah jarak antar pipa $5 \mathrm{~cm}$ dikarenakan perpindahan panas konveksi yang terjadi lebih besar dan efisiensi perubahan suhu rata-rata pada intensitas matahari tertinggi lebih tinggi dibandingkan jarak antar pipa 7 $\mathrm{cm}$ dan jarak antar pipa $9 \mathrm{~cm}$.

\section{Saran}

1. Perlu dilakukan penelitian lanjut dengan memperbesar dimensi kolektor pemanas dan merubah diameter pipa tembaga dengan ukuran yang lebih besar dan jarak antar pipa lebih dekat

2. Lakukan pengujian dan pengambilan data dengan waktu lebih lama sehingga di dapat data yang lebih akurat

\section{Daftar Pustaka}

[1]. Sucipta, M., Astawa, K., \& Argha Dharmawan, A. A. (2012). Performansi Kolektor Surya Tubular Terkonsentrasi Dengan Pipa Penyerap Dibentuk Anulus Dengan Variasi Posisi Pipa Penyerap. Jurnal Energi Dan Manufaktur, 5(1).

[2]. Sumarsono, M. (2012). Optimasi Jumlah Pipa-Pemanas Terhadap Kinerja Kolektor Surya Pemanas Air. Jurnal Teknologi Energi, 1(1).

[3]. Mustofa Dan Rustan Hatib, 2014, 'Konfigurasi SerpentineParalel Dan ParalelSerpentine Pada Pipa Fluida Pemanas Air Surya Sistem Thermosipon', Jurnal Mekanikal Vol. 5, No. 1, Hal. 464-469, Universitas Tadulako.

[4]. Kristanto, P., \& San, Y. K. (2004). Pengaruh Tebal Plat Dan Jarak Antar Pipa Terhadap Performansi Kolektor Surya Plat Datar. Jurnal Teknik Mesin, 3(2), pp-47.

[5]. Sudrajat, S. E., \& Santosa, I. (2014). Perancangan Solar Water Heater Jenis Plat Datar Temperatur Medium Untuk Aplikasi Penghangat Air Mandi. Jurnal Teknologi, $7(2)$.

[6]. Ichwan Nurhalim, 2011, 'Rancang Bangun Dan Pengujian Unjuk Kerja Alat Penukar Kalor Tipe Serpentine Pada Split Air Conditioning Water Heater', Departemen Teknik Mesin, Universitas Indonesia, Depok.

[7]. Caturwati, N. K., Yuswardi, Y., \& Nino, S. (2013). Peningkatan 
Efisiensi Absorbsi Radiasi Matahari pada Solar Water Heater dengan Pelapisan Warna Hitam. Jurnal Energi Dan Manufaktur, 5(1).

[8]. Luqman Buchori, 2004, 'Buku Ajar Perpindahan Panas Bagian 1', Universitas Diponegoro, Semarang.

[9]. Frank Kreith, 1991, Prinsip - Prinsip perpindahan Panas Edisi 3, University Of Colorado, Jakarta: Penerbit Erlangga.

[10]. Pramirtha, S., \& Dwiyantoro, B. A. (2015). Studi Eksperimental Pengaruh Laju Aliran Air Terhadap Efisiensi Thermal pada Kolektor Surya Pemanas Air dengan Penambahan External Helical Fins pada Pipa. Jurnal Teknik ITS, 4(1), B68-B73. 